\title{
Ukraine Pension System and Financial Markets: Conceptualization Problems
}

\author{
Nataliya Rad (Donetsk National University of Economics and Trade, Ukraine)
}

\begin{abstract}
The paper analyzes some aspects of Ukrainian pension system formation. All its three levels taken as a whole are a real source for the formation of domestic investment resources and implementation of their potential through financial market instruments. At the present stage relationship of these two institutes is pronounced in the frameworks of non-state pension funds. Implementation of the accumulative level of pension system has only to accelerate processes at work. Investigation is focused on the problems of integrating pension system investment resource into financial market infrastructure. It is noted that in the current conditions infrastructure of domestic financial market is being formed. Its instruments are developed and are functioning irregularly. However, there exist general problems that require their solution. They are related to insufficient operational capacity and efficiency of financial market regulating mechanism and other factors. Analysis of the quality of implementation of financial market basic macroeconomic function associated with redistribution of pension savings allowed us to make conclusion on the incompatibility of the achieved level of its development with the current needs adjusted for pension reform. Proposals for improvement of the concept of pension system and financial market along the lines of their harmonization and enhancement of the functioning efficiency in the context of social-economic development of Ukraine are worked out.
\end{abstract}

JEL codes: D53, G23, G28

\section{Problem definition}

Pension system reforming is part of transformational processes which are under way in Ukraine in recent times. Status of the social welfare state declared by the Ukrainian Constitution provides for formation of high social standards for its citizens (Verkhovna Rada of Ukraine, 1996). Pension system transformation that has been starting in 2004 was aimed at solution of a wide range of social problems. Insurance principles that determine dependence of pension amount on the length of pensionable service and wage level (insurance contributions) were accepted as a basis for a new pension system concept (Verkhovna Rada of Ukraine, 2003a). However, opportunities of insurance mechanism are far beyond the scope of task performance. Functioning of the second and third levels gives opportunity to form domestic investment resources which can be directed to development of the economy. Effective implementation of investment opportunities of financial defined contributions and occupational retirement insurance is possible in the presence of developed financial market, its infrastructure and instruments. The nature, backbone and features of domestic pension scheme and financial market formation under present-day conditions are studied in the works of the leading Ukrainian scientists and practicians, in particular, Yu. Kovalenko, V. Evstegneeva, G. Tereshchenko, S. Naumenkova, G. Belinskaya, S. Kulpinskaya, G. Degtyaryov, B. Zaitchuk and many other. In spite of strong conceptual framework of the items mentioned above, problems related to formation of financial market in the context of pension system development continue to call for sequential analysis and evaluation of functioning. This explains the urgency of our research. Thus, object of the paper is the analysis of formation of pension system investment resources and their integration into the infrastructure of financial market; identification of its conformity to the needs of the developing pension system; working out guidelines for improvement of the pension system and financial market concept in the context of social and economic development of society.

\section{Problem description}

Nowadays mechanism of three-level pension scheme potentially covers all categories of citizens and business activity participants and depends on the level of participation of each of these categories. Besides, efficiency of financial defined contributions and private pension insurance system depends on the level of return of investment resources. It is pertinent to note that definitions of the essence and interpretation of the notion financial market are many-sided. Their basis forms the categories financial assets, financial instruments, financial institutions, financial intermediaries (Kovalenko, 2010). Yuriy and Lutsishin interpret financial market as a complex of economic relations connected with distribution of financial resources, purchase and sale of temporarily disposable monetary resources and securities (Yuriy and Lutsishin, 2010). It must be emphasized that formation of financial market is influenced by a lot of factors shown in Figure 1. 


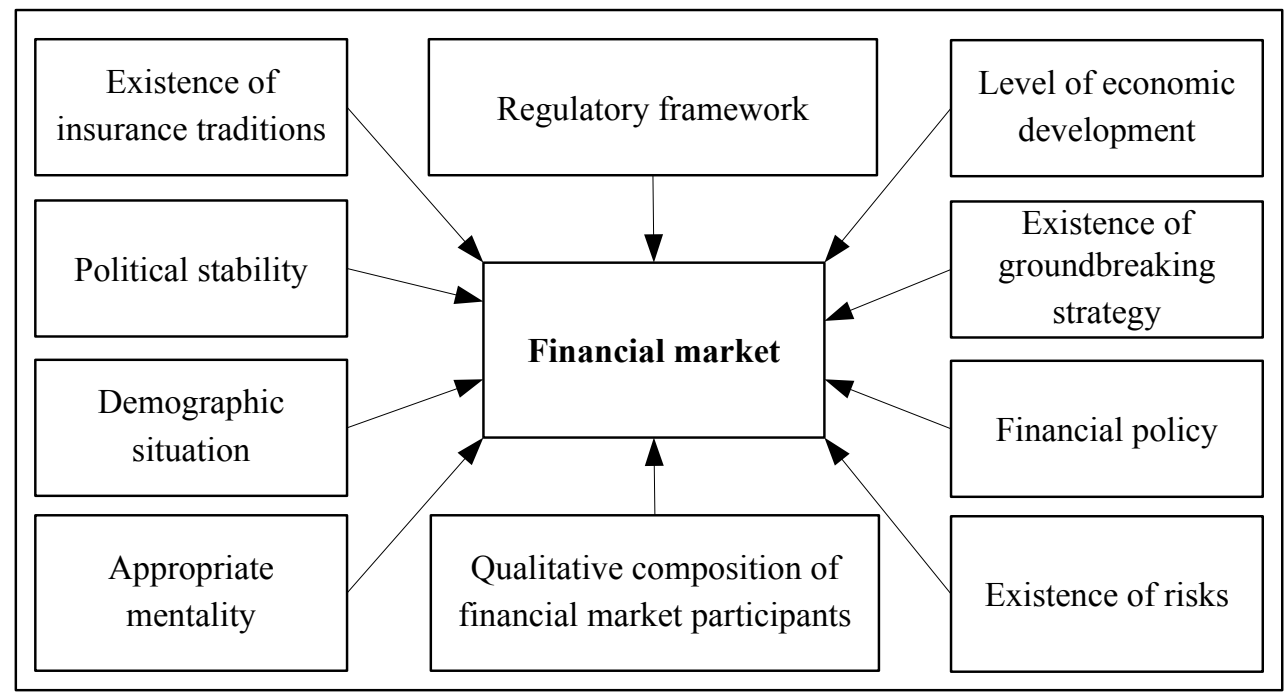

Figure 1. Factors influencing development of financial market.

Among the above listed factors we can identify those inherent to financial defined contributions: indicators of demographic development, existence of insurance traditions, appropriate mentality (that implies necessity of the availability of such human qualities as responsibility for financial security of chair days, capability of adequate assessment of pension assets formation and decision-making, prudence).

Financial market implementing the above mentioned spectrum of functions also influences other spheres of society shown in Figure 2.

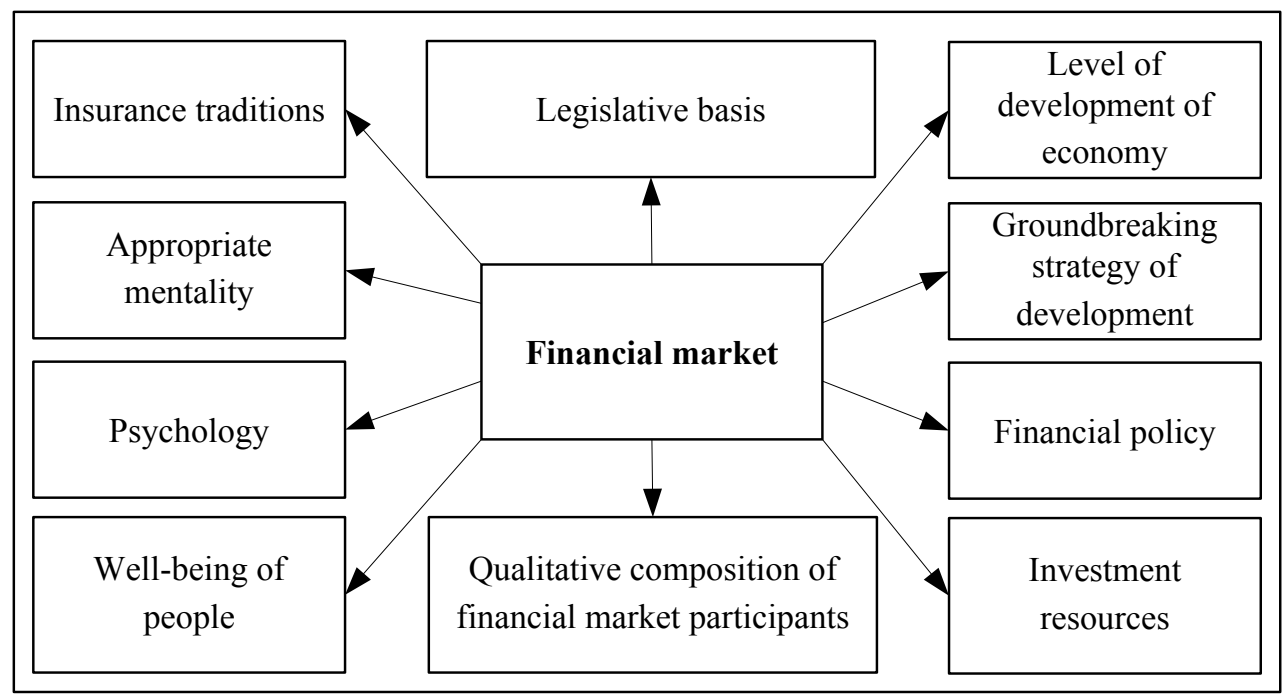

Figure 2. Components of financial market that influence development of society.

Present mechanism of three-level pension system potentially covers all categories of citizens and participants of economic activity. It should be noted that its accumulative elements play important role of supplier of financial resources for their further transformation into investment resources. In interaction they actualize a complex of purposes shown in Table 1.

\begin{tabular}{|c|c|c|}
\hline Purposes & Mechanism of actualization & Expected effect \\
\hline Improvement of living standard & $\begin{array}{c}\text { Diversification of insurance contributions of } \\
\text { the insured }\end{array}$ & High level of pension payments \\
\hline Activation of economic activity & $\begin{array}{c}\text { Formation of inexpensive investment } \\
\text { resources }\end{array}$ & $\begin{array}{c}\text { Growth of number of work places and } \\
\text { employees }\end{array}$ \\
\hline $\begin{array}{c}\text { Investment character of } \\
\text { development of economy }\end{array}$ & $\begin{array}{c}\text { Formation of inexpensive investment } \\
\text { resources }\end{array}$ & Improvement of competitiveness \\
\hline $\begin{array}{c}\text { Improvement of pension system } \\
\text { financial stability }\end{array}$ & $\begin{array}{c}\text { Maximal coverage by participation in three- } \\
\text { level pension systems }\end{array}$ & $\begin{array}{c}\text { Sufficiency of funds in the pension } \\
\text { system for fulfillment of obligations }\end{array}$ \\
\hline $\begin{array}{c}\text { Improvement of quality of inter- } \\
\text { age relations }\end{array}$ & $\begin{array}{c}\text { Improvement of confidence in pension } \\
\text { system }\end{array}$ & $\begin{array}{c}\text { Participation in three-level pension } \\
\text { systems }\end{array}$ \\
\hline
\end{tabular}

Table 1. Target guiding lines for functioning of financial market and pension fund 
We should emphasize that target guiding lines for interaction of financial market and pension system are both of material and non-material character. Financial market includes credit market (market of banking credits), equity market (including market of derivative financial instruments), currency-monetary market, market of insurance services and gold market (Supakshin, 2008). In exercising its activity financial market realizes functions manifestation of which can be traced through indicators of pension system shown in Table 2 .

\begin{tabular}{|c|c|c|}
\hline $\begin{array}{c}\text { Function } \\
\text { description }\end{array}$ & $\begin{array}{c}\text { Manifestation through financial } \\
\text { market }\end{array}$ & Manifestation through pension system \\
\hline Distributive & $\begin{array}{l}\text { Re-distribution of financial resources } \\
\text { (savings) }\end{array}$ & Capitalization of monetary savings of the insured \\
\hline Investment & Investment into economy & $\begin{array}{l}\text { Creation of new work places, wage raise (rise of } \\
\text { income), broadening the circle of the insured }\end{array}$ \\
\hline Economic & Development of branches of economy & $\begin{array}{l}\text { Creation of new work places, wage raise (rise of } \\
\text { income), broadening the circle of the insured }\end{array}$ \\
\hline Financial & $\begin{array}{c}\text { Development of instruments of financial } \\
\text { system of the state }\end{array}$ & Capitalization of monetary savings of the insured \\
\hline $\begin{array}{l}\text { Groundbreak } \\
\text { ing }\end{array}$ & $\begin{array}{l}\text { Development of groundbreaking } \\
\text { branches of production }\end{array}$ & $\begin{array}{l}\text { Creation of new work places, wage raise (rise of } \\
\text { income), broadening the circle of the insured }\end{array}$ \\
\hline Incentive & $\begin{array}{l}\text { Induces positive processes in } \\
\text { development of economy and other } \\
\text { spheres of society }\end{array}$ & $\begin{array}{c}\text { Participation in accumulative forms of retirement } \\
\text { insurance }\end{array}$ \\
\hline Educational & $\begin{array}{l}\text { Promotes formation of financial initiative } \\
\text { and responsibility of citizens }\end{array}$ & $\begin{array}{c}\text { Participation in accumulative forms of retirement } \\
\text { insurance }\end{array}$ \\
\hline
\end{tabular}

Table 2. The main functions of financial market in the context of pension system functioning.

Financial market is characterized by complexity of organization, a rattling good variability speed, unpredictability of behavior and subsequent results. The basis for mutual relations of financial market and pension system institutions is social component related to formation of pension payments. This feature requires definiteness, stability and predictability of the results in the longer term. Within the context of those set forth the category financial market in the author's opinion can be represented as a sphere of social relations for redistribution of pension assets through instruments of financial market in the form of investment resources in Ukrainian economics, the result of which is obtaining capitalization products for respective pension payments (see Figure 3).

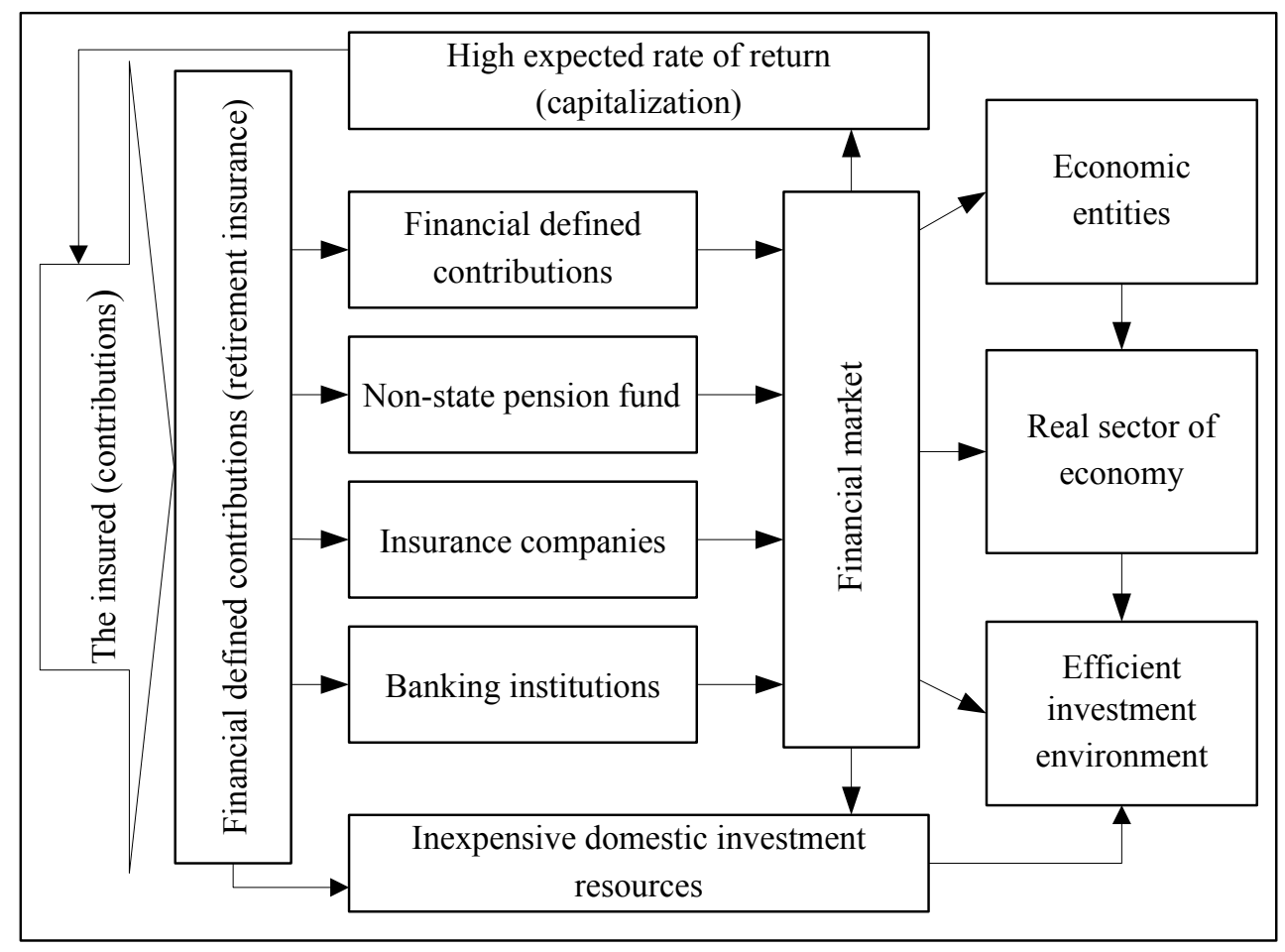

Figure 3. Structural-logic diagram of financial defined contributions (retirement insurance).

It should be stressed that the basis for interaction of financial market and pension system institutions is interage interaction of its main participants: the insured and pensioners (see Figure 4). 


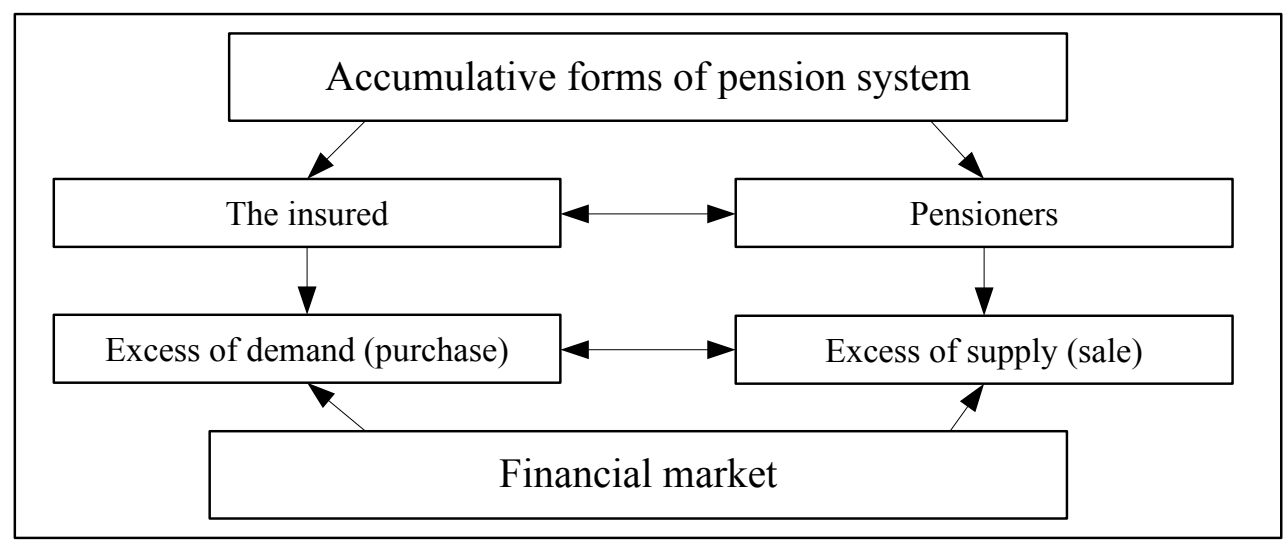

Figure 4. The Structural-logic scheme of the interaction of accumulating pension insurance in the financial market

The main (demographic) dependence among the mentioned categories of participants causes considerable changes in functioning of financial markets. For example, excess of the number of the insured (over pensioners) forces up the flow of financial resources and demand for financial market instruments that contributes to their development and growth of prices. In case when the number of pensioners begins exceeding the number of the insured necessity to release funds for extinction of obligations to pensioners arises. This results in the corresponding response of financial market: increase in sales operations and parallel decrease in demand (a cut in prices) for securities. This problem requires study and regulation concerning decrease of risks related to demographic (inter-age) differences in functioning of accumulative pension systems (financial defined contributions) in financial market.

In ideal conditions the process of investing funds of defined contribution pension systems assumes availability of integrated investment strategy and appropriate investment objects. However, there is a particularity of behavior of the participants of relations related to the functioning of pension fund resources as investment resources. It consists in that the insured parties expect maximal capitalization of investments, and business activity participants assume obtaining inexpensive domestic investment resources. For that reason making of the optimum relationship of parameters is required.

It should be noted that activity of defined contribution pension systems also exerts substantial influence on financial market functioning (see Figure 5).

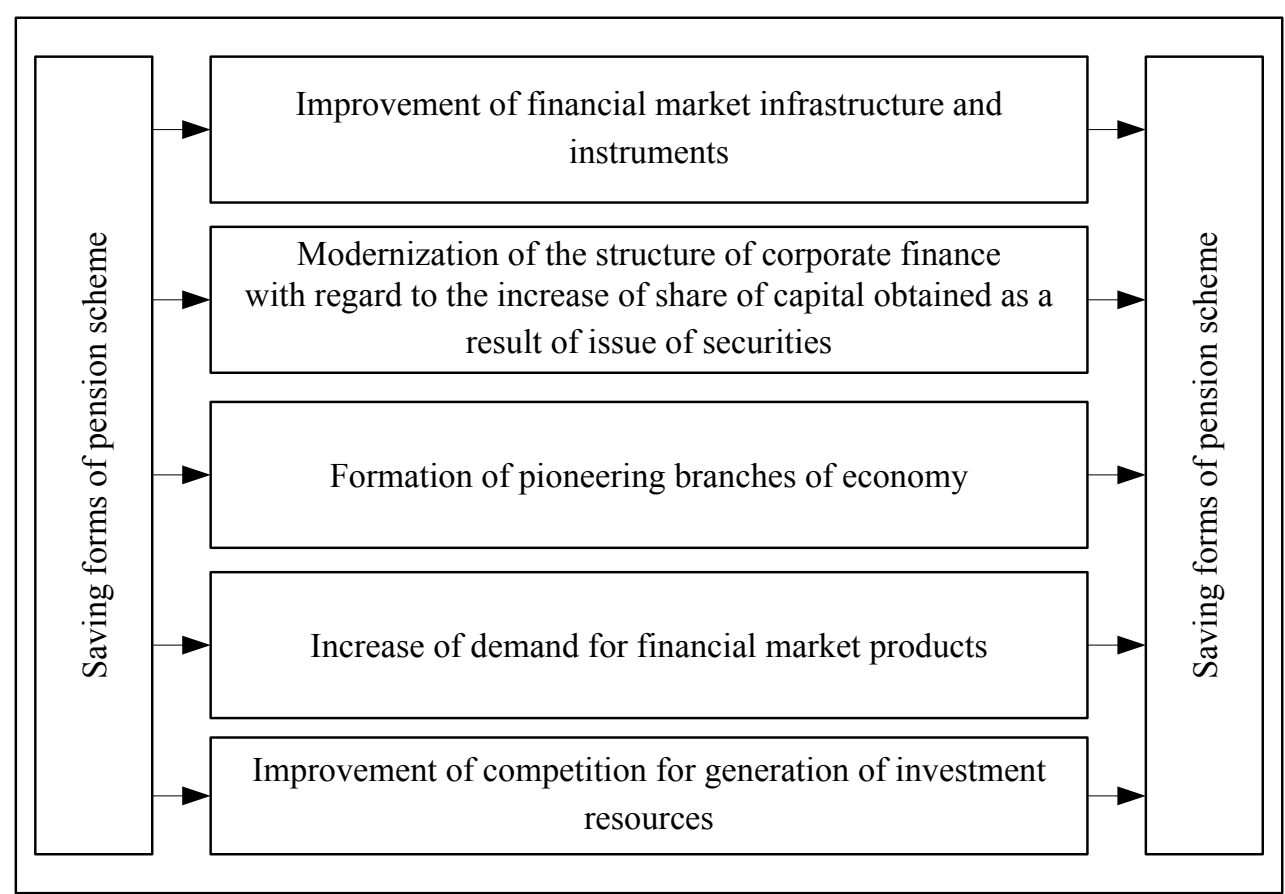

Figure 5. Diagram of the influence of defined contribution pension systems on financial deepening.

Particularities of the functioning of non-state pension system in the current context of financial market are identified. They consist in division of assets of the insured parties and founding shareholders; separation of the 
processes of administration, management and preservation of assets and also diversification of directions for investment of pension fund assets (Tkachenko and Tsikanovska, 2010). However, it should be appreciated that diversification of pension system financial resources is limited by provisions of law (see Table 3 ).

\begin{tabular}{|c|c|c|}
\hline Type of investment instrument & $\begin{array}{c}\text { Limitation of investment in } \\
\text { defined contribution pension } \\
\text { system }\end{array}$ & $\begin{array}{c}\text { Limitation of investment } \\
\text { in non-state pension system }\end{array}$ \\
\hline $\begin{array}{c}\text { Cash in bank and deposit accounts, } \\
\text { savings certificates }\end{array}$ & 50 & 40 \\
\hline Government securities & 50 & 50 \\
\hline Ad bonds & 10 & 20 \\
\hline Corporate bonds of Ukrainian issuers & 20 & 40 \\
\hline Stocks of Ukrainian issuers & 40 & 40 \\
\hline $\begin{array}{c}\text { Government securities of foreign } \\
\text { issuers }\end{array}$ & $\begin{array}{c}5 \text { and not more than } 10 \% \\
\text { in securities of one issuer }\end{array}$ & 20 \\
\hline $\begin{array}{c}\text { Other assets not prohibited by } \\
\text { Ukrainian legislation }\end{array}$ & 5 & 5 \\
\hline
\end{tabular}

Table 3. Limitations of investment of pension assets.

It is pertinent to note that consolidated profit (negative profit) from investment of pension fund assets consists of consolidated profit (negative profit) from implementation of operations with its assets, passive incomes (gains on assets placed in securities) (Verkhovna Rada of Ukraine, 2003b). Structure of actual investment of assets of non-state pension funds in 2010 is shown in Figure 6.

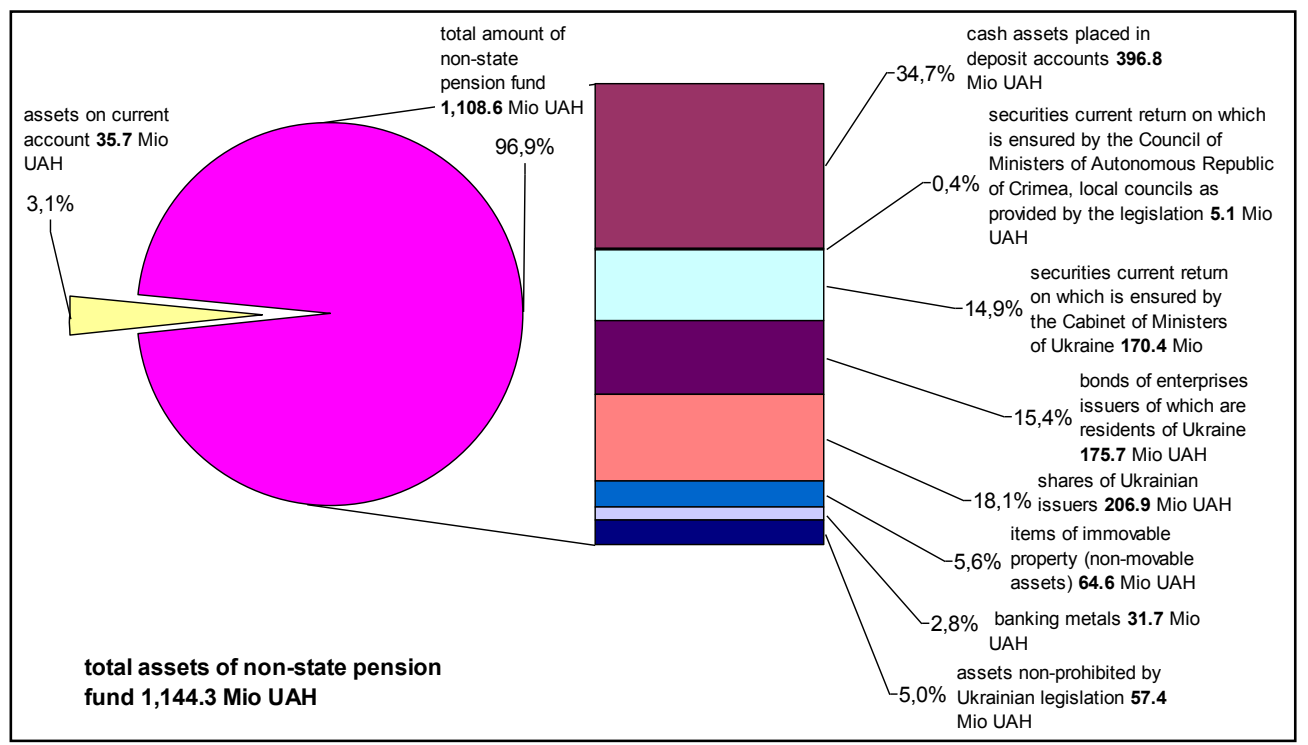

Figure 6. Structure of investment of assets of Ukrainian non-state pension funds in 2010.

Data in the diagram above shows full-scale range of investment instruments (State Commission for Regulation of Financial Services Markets, 2010). However, evident become risks that accompany operational investment strategy. In the structure of consolidated portfolio the largest ratio falls within the instruments liable to risks of instability the confirmation of which serves recent crisis of banking sector. In the structure of the shares of domestic issuers the primary is the share of key branches (metallurgical, energy, engineering, chemical industries) which have high degree of dependence on economic situation and level of world market prices. Consequently, for efficient application of pension system investment resources definition of the integrated groundbreaking development strategy is required taking into account capacity of pension system resources for long term perspective. Function of saving forms of pension system also requires construction of the right strategy. Administration of pension fund cash flows is characterized by large volumes of changing information that requires quick information gathering, systematization, assessment, and decision making. Pension funds feature either aggressive-character strategy that ensures high level of income and risks or conservative strategy in conditions of low level of incomes and minimal riskiness of operations. Mixed-character strategies are also present. According to analysts' estimates, pension fund functioning strategy which amount of capitalization of invested funds exceeds rate of inflation plus 4-5\% per annum appear worthy of positive estimation. However, there are opinions on the minimal criterion of positive estimation for pension fund functioning provided saving citizens' retirement savings. Thus, we need defining the optimal parameters of investment strategy for defined 
contribution pension systems which would combine sufficient return level and protection against risks of loss (depreciation) of retirement assets of the insured.

\section{Conclusions}

Summarizing all above-mentioned we may conclude that pension system in Ukraine is an efficient mechanism for formation of investment resources, development of financial market and economy. To achieve gains in this process, to our opinion, it is necessary:

i. To define parameters of the optimal correlation of capitalization of pension fund investment resources through financial market for its participants.

ii. To work out national groundbreaking strategy taking into account capacity of pension system investment resources for their effective application for long-term perspective.

iii. To create algorithm for construction of the efficient pension fund investment strategy, that would combine sufficient return level and protection against risks of loss or depreciation of retirement assets of the insured.

iv. To work out protective mechanism against demographic differences in the system of financial defined contributions (accumulative pension systems) and financial market interrelations.

Implementation of the abovementioned measures will allow activating the process of functioning of the third and introduction of the second level of pension system and also will contribute to financial market development in the context of realization of national priorities for innovative economic development.

\section{References}

- Verkhovna Rada of Ukraine, 1996. Constitution of Ukraine, http//zakon1.rada.gov.ua/cgibin/laws/main.cgi?nreg=254\%EA\%2F96-\%E2\%F0

- Verkhovna Rada of Ukraine, 2003. Act of Ukraine no. 1058 On the obligatory state pension insurance, http://zakon1.rada.gov.ua/cgi-bin/laws/main.cgi?nreg=1058-15

- Kovalenko, 2010. "Modern financial market structure”, Finances of Ukraine, 178, p. 92.

- Yuriy and Lutsishin, 2010. "Financial service market as an institutional basis of market economy", Finances of Ukraine, 180, p. 54.

- Supakshin, 2008. Financial markets and economic policy of Russia. Nauchny expert, Moscow.

- Tkachenko and Tsikanovska, 2010. "The role of non-state pension funds in development of Ukrainian financial market", Finances Ukraine, 181, p. 73.

- Verkhovna Rada of Ukraine, 2003. Act of Ukraine no. 1057 On the non-state pension provision, http://zakon1.rada.gov.ua/cgi-bin/laws/main.cgi?nreg=1057-14

- State Commission for Regulation of Financial Services Markets, 2010. Results of non-state pension provision system development in 2010, http://www.dfp.gov.ua 